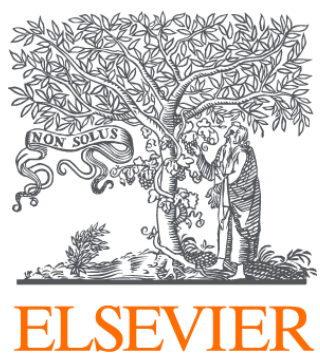

Since January 2020 Elsevier has created a COVID-19 resource centre with free information in English and Mandarin on the novel coronavirus COVID-

19. The COVID-19 resource centre is hosted on Elsevier Connect, the company's public news and information website.

Elsevier hereby grants permission to make all its COVID-19-related research that is available on the COVID-19 resource centre - including this research content - immediately available in PubMed Central and other publicly funded repositories, such as the WHO COVID database with rights for unrestricted research re-use and analyses in any form or by any means with acknowledgement of the original source. These permissions are granted for free by Elsevier for as long as the COVID-19 resource centre remains active. 


\title{
Metropolitan wastewater analysis for COVID-19 epidemiological surveillance
}

\author{
Walter Randazzo a,b, Enric Cuevas-Ferrando ${ }^{a}$, Rafael Sanjuán ${ }^{c}$, Pilar Domingo-Calap ${ }^{\text {c, d, *, }}$ \\ Gloria Sánchez ${ }^{\mathrm{a}, * *}$ \\ ${ }^{a}$ Department of Preservation and Food Safety Technologies, Instituto de Agroquímica y Tecnología de Alimentos - Consejo Superior de Investigaciones Científicas (IATA- \\ CSIC), Av. Agustín Escardino 7, Paterna, 46980, Valencia, Spain \\ b Department of Microbiology and Ecology, Universitat de Valencia, Av. Dr. Moliner, 50, Burjassot, 46100, Valencia, Spain \\ ${ }^{\mathrm{c}}$ Institute for Integrative Systems Biology, $I^{2}$ SysBio, Universitat de Valencia-CSIC, 46980, Paterna, Spain \\ d Department of Genetics, Universitat de Valencia, 46980, Paterna, Spain
}

\section{A R T I C L E I N F O}

\section{Keywords:}

Epidemiological surveillance

SARS-CoV-2

COVID-19

Early warning

\begin{abstract}
A B S T R A C T
The COVID-19 disease, caused by severe acute respiratory syndrome coronavirus 2 (SARS-CoV-2), is a rapidly emerging pandemic which has enforced extreme containment measures worldwide. In the absence of a vaccine or efficient treatment, cost-effective epidemiological surveillance strategies are urgently needed. Here, we have used RT-qPCR for SARS-CoV-2 detection in a series of longitudinal metropolitan wastewaters samples collected from February to April 2020, during the earliest stages of the epidemic in the Region of Valencia, Spain. We were able to consistently detect SARS-CoV-2 RNA in samples taken in late February, when communicated cases in that region were only incipient. We also find that the wastewater viral RNA context increased rapidly and anticipated the subsequent ascent in the number of declared cases. Our results strongly suggest that the virus was undergoing community transmission earlier than previously believed, and suggest that wastewater analysis could be sensitive and cost-effective strategy for COVID-19 epidemiological surveillance. Routine implementation of this surveillance tool would significantly improve our preparedness against new or re-occurring viral outbreaks.
\end{abstract}

\section{Introduction}

The emergence of severe acute respiratory syndrome coronavirus 2 (SARS-CoV-2) in Wuhan, China, has rapidly led to a pandemic scenario, with over 12 million COVID-19 confirmed cases globally as of July 9, 2020. COVID-19 symptoms are varied and often non-specific, including fever, cough, and diarrhea, among others. A non-negligible percentage of infected people develop pneumonia, which can subsequently lead to severe respiratory distress requiring mechanical ventilation, organ failure, viral sepsis, and death (Li et al., 2020). The widespread nature of the pandemics and the lack of easy symptom-based diagnosis, treatment, or vaccine has enforced drastic and extremely costly epidemiological control measures including worldwide lockdowns. Whereas massive RT-qPCR testing campaigns are being deployed in many countries to assess the actual prevalence of the virus, this is not a feasible surveillance strategy for the general population over the long term.

At the time this study was completed (May 13, 2020), Spain stood as the second most extensively affected country worldwide with over 228,000 confirmed COVID-19 infections and more than 27,000 deaths. The first three confirmed cases in the Iberian Peninsula were communicated on February 25, 2020 in Madrid, Barcelona, and Villareal, a small town nearby the city of Valencia. Furthermore, a retrospective analysis carried out in March showed that the first death in Spain from COVID-19 actually occurred on February 13 in Valencia. Therefore, the Valencian Region constituted the earliest known COVID-19 spot in Spain (Ministerio de Sanidad, Consumo y Bienestar Social - Professionals Enfermedad por nuevo coronavirus, COVID-19). However, at the time, it was assumed that no community transmission was ongoing and, as a result, major containment measures were not enforced until March 15.

Setting up feasible and reliable methods for SARS-CoV-2 epidemiological surveillance is of utmost importance to successfully combat this pandemic virus and improve our preparedness in the event of viral reemergences. Although SARS-CoV-2 is primarily a respiratory, airborne virus, previous studies with the related SARS-CoV-1 (the causative agent

\footnotetext{
* Corresponding author. Institute for Integrative Systems Biology, I²SysBio, Universitat de València-CSIC, 46980, Paterna, Spain.

** Corresponding author.

E-mail addresses: pilar.domingo@uv.es (P. Domingo-Calap), gloriasanchez@iata.csic.es (G. Sánchez).
} 
of the 2003 SARS outbreak) suggested the possibility of fecal-oral transmission based on detection of viral RNA by RT-qPCR in the stools of patients (Duan et al., 2003). Recent studies indicate that SARS-CoV-2 can be also excreted in feces and urine in asymptomatic carriers and in recently recovered patients (Cheung et al., 2020; Lescure et al., 2020; Lo et al., 2020; Sun et al., 2020; Wang et al., 2020; Wu et al., 2020; Xing et al., 2020; Zhang et al., 2020). Specifically, viral RNA was detected in feces up to 10 days after viral clearance from the respiratory tract, regardless of disease severity (Chen et al., 2020).

This implies that wastewaters may contain viral particles or viral RNA that could be used as an epidemiological surveillance tool. Wastewaters can also collect viruses present in the oral cavity and upper respiratory tract that are shed during personal hygiene. Compared to systematic testing of individuals, wastewater analysis is obviously less invasive, simpler and cheaper, but the sensitivity and reliability of this method remains to be shown. Previous work has established similar methods for the epidemiological surveillance of enteric viruses including norovirus, rotavirus (Santiso-Bellón et al., 2020), hepatitis E virus (Cuevas-Ferrando et al., 2020), influenza, and poliovirus (Heijnen and Medema, 2011; Hellmér et al., 2014; Hovi et al., 2012), and recent publications (Ahmed et al., 2020; Bivins et al., 2020; Haramoto et al., 2020; La Rosa et al., 2020; Lodder and de Roda Husman, 2020; Medema et al., 2020; Randazzo et al., 2020) suggest that COVID-19 detection in sewage is technically feasible, based on preliminary results obtained from a limited number of samples in China, Australia, the Netherlands, Italy, Japan, and USA. Here, we have analyzed sewage water collected in the Valencian region from February to April 2020 to assess our ability to detect the virus during the earliest stages of an outbreak.

\section{Materials and methods}

\subsection{Wastewater sampling}

Samples of metropolitan wastewater from Valencia (Spain) were taken at different time points in a two-month longitudinal study spanning from February 12 to April 14, 2020. Specifically, samples were taken from wastewater treatment plants Pinedo 1, Pinedo 2 and QuartBenàger, all belonging to the Empresa Pública de Saneamiento de Aguas Residuales (Generalitat Valenciana). Grab samples of $200 \mathrm{~mL}$ of sewage water were collected in the morning, between 10 a.m. and 12 a.m. in all cases. Some samples were collected before and after wastewater treatment, and all samples were kept at $4{ }^{\circ} \mathrm{C}$ until analysis. Previous studies have shown that SARS-CoV-2 infectivity is stable at $4{ }^{\circ} \mathrm{C}$ for at least 14 days (Chin et al., 2020), although little is known about RNA stability. Since our earliest samples remained stored at $4{ }^{\circ} \mathrm{C}$ for almost two months, we cannot discard viral RNA degradation over time. However, this would lead to underestimation of the viral RNA present in these samples, which ultimately would strengthen our conclusion that RT-qPCR wastewater analysis allows early detection of disease outbreaks.

\subsection{Sample processing and RNA extraction}

Viral concentration was carried out by aluminum-driven flocculation. For this, $200 \mathrm{~mL}$ water samples were adjusted to $\mathrm{pH} 6.0$ and an $\mathrm{Al}$ $(\mathrm{OH})_{3}$ precipitate was formed by adding $1: 100 \mathrm{v}$ : $\mathrm{v}$ of $0.9 \mathrm{~N} \mathrm{AlCl}_{3}$ solution. After $\mathrm{pH}$ readjustment to 6.0, samples were agitated slowly for 15 $\mathrm{min}$ at room temperature. Precipitates were collected by centrifugation at $1700 \times g$ for $20 \mathrm{~min}$. Pellets were resuspended into $10 \mathrm{~mL}$ of $3 \%$ beef extract ( $\mathrm{pH} 7.4$ ), and samples were shaken for $10 \mathrm{~min}$ at $150 \mathrm{rpm}$ (Randazzo et al., 2019). A concentrate was then formed by centrifugation at $1900 \times \mathrm{g}$ for $30 \mathrm{~min}$ and the pellet resuspended in $1 \mathrm{~mL}$ of PBS ("9510 detection of enteric viruses (2017)," 2018). As a process control, samples were spiked with $10^{5}$ PCR units of mengovirus vMC0 (CECT 100000) following a protocol similar to ISO 15216-2:2017 used in food products. This procedure has been previously validated for non-enveloped viruses (Cuevas-Ferrando et al., 2020; Randazzo et al., 2019) and more recently with a porcine epidemic diarrhea virus, an enveloped virus member of the Coronaviridae family used as a SARS-CoV-2 surrogate (Randazzo et al., 2020). RNA extraction was performed using the Nucleospin RNA virus Kit (Macherey-Nagel) following the recommended protocols and using a Plant RNA Isolation Aid (Ambion) pre-treatment (Cuevas-Ferrando et al., 2020).

\subsection{SARS-CoV-2 RT- $q P C R$}

The presence of SARS-CoV-2 was determined using the PrimeScript ${ }^{\mathrm{TM}}$ One Step RT-PCR Kit and the RT-qPCR diagnostic panel assays validated by the US Centers for Disease Control and Prevention (2019nCoV RUO Kit) using the positive control (2019-nCoV_N_Positive Control) provided by IDT (Integrated DNA Technologies). The RT-qPCR was carried out following the manufacturer's instructions, recommended standards, and positive controls in a LightCycler 480 (Roche Diagnostics) instrument. Each RNA extract was analyzed in duplicate. Undiluted and tenfold diluted RNA extracts were analyzed for mengovirus to account for the presence of RT-qPCRs inhibitors. A calibration curve was performed using the 2019-nCoV_N_Positive Control provided by IDT. For each RT-qPCR run, a series of three positive and negative controls (extraction and PCR) were included. Cycle threshold (Ct) values were used to calculate $\mathrm{gc} / \mathrm{L}$ in the original sample. $\mathrm{Ct}$ values lower than 40 were considered positive for SARS-CoV-2, as proposed previously (Wang et al., 2020). In all cases, the internal mengovirus control showed recovery rates $>1 \%$, an acceptable value according to previous work (Haramoto et al., 2018).

\subsection{Epidemiological data}

The sewage treatment plants under study collected wastewaters from approximately 1,200,000 inhabitants in 22 townships of the Valencian metropolitan area (Alaquas, Albal, Alcasser, Aldaia, Alfafar, Benetusser, Beniparell, Burjassot, Catarroja, Llocnou de la Corona, Manises, Massanassa, Mislata, Paiporta, Picanya, Picassent, Quart de Poblet, Sedavi, Silla, Torrent, Valencia, and Xirivella). The number of declared active cases per day for the Region of Valencia was obtained from Conselleria de Sanidad Universal y Salud Pública (Generalitat Valenciana).

\section{Results and discussion}

Here, we show that SARS-CoV-2 can be reproducibly detected by RTqPCR in longitudinal samples from sewage treatment plants that receive wastewaters from over one million inhabitants in the metropolitan area of Valencia, Spain. We analyzed 15 samples taken between February 12 and April 14, 2020 at three wastewater treatment plants. Following concentration of viral content by flocculation, a standard RT-qPCR procedure allowed us to detect SARS-CoV-2 RNA in 12/12 samples collected from March 9 to April 14, 2020, with quantification cycles (Ct) values ranging between 34.00 and 37.84 , correspondingly revealing between 5.22 and $5.99 \log _{10}$ genomic copies (gc)/L (Table 1). Briefly, SARS-CoV-2 RNA was quantified as gc by plotting the $\mathrm{Ct}$ to an external standard curve built with 10 -fold serial dilution of a quantified plasmid control (IDT). Calibration curves for N1 $\left(\log _{10} \mathrm{gc} / \mathrm{L}=-3.3774 \mathrm{Ct}+\right.$ $\left.41.515, \mathrm{r}^{2}=0.95\right)$, and $\mathrm{N} 2\left(\log _{10} \mathrm{gc} / \mathrm{L}=-3.7752 \mathrm{Ct}+43.951, \mathrm{r}^{2}=\right.$ 0.989 ), showed a linear dynamic range between 50 and $5 \times 10^{4}$. The limit of detection (LOD) was thus $50 \mathrm{gc}$ per reaction, with $\mathrm{Ct}$ values of $37.05 \pm 0.77$ and $38.12 \pm 0.24$ for $\mathrm{N} 1$ and N2, respectively. The theoretical quantitation limits were 4.45 and $4.91 \log _{10} \mathrm{gc} / \mathrm{L}$ for N1 and N2, respectively. SARS-CoV-2 RNA was not detected in a single sample from February 12, but was detected in one of the two samples collected in February 24 for RT-qPCR region N2, whereas region N1 remained negative for this time point. Comparison of RT-qPCR primers and probes for SARS-CoV-2 diagnostics suggests that N1 and N2 primers used here are efficient for SARS-CoV-2 RNA detection (Corman et al., 2020; Nalla 
Table 1

Detection of SARS-CoV-2 RNA by RT-qPCR in untreated wastewater samples from three treatment plants in the metropolitan region of Valencia, Spain.

\begin{tabular}{|c|c|c|c|c|c|c|}
\hline $\begin{array}{l}\text { Sampling } \\
\text { date } \\
(2020)\end{array}$ & $\begin{array}{l}\text { Water } \\
\text { treatment } \\
\text { plant }\end{array}$ & $\begin{array}{l}\text { Recovery } \\
\text { control } \\
(\%)\end{array}$ & $\begin{array}{l}\mathrm{Ct} \\
(\mathrm{N} 1)^{\mathrm{a}}\end{array}$ & $\begin{array}{l}\log _{10} \\
\text { gc/L } \\
\pm \mathrm{SD} \\
(\mathrm{N} 1)^{\mathrm{a}}\end{array}$ & $\begin{array}{l}\mathrm{Ct} \\
(\mathrm{N} 2)^{\mathrm{b}}\end{array}$ & $\begin{array}{l}\log _{10} \\
\text { gc/L } \\
\pm \text { SD } \\
(\mathrm{N} 2)^{\mathrm{b}}\end{array}$ \\
\hline $\begin{array}{l}\text { February } \\
12\end{array}$ & $\begin{array}{l}\text { Quart- } \\
\text { Benàger }\end{array}$ & 2.56 & $\mathrm{nd}^{\mathrm{c}}$ & $\mathrm{nd}^{\mathrm{c}}$ & $\mathrm{nd}^{\mathrm{c}}$ & $\mathrm{nd}^{\mathrm{c}}$ \\
\hline February & Pinedo 1 & 4.71 & $\mathrm{nd}^{\mathrm{c}}$ & $\mathrm{nd}^{\mathrm{c}}$ & $\mathrm{nd}^{\mathrm{c}}$ & $\mathrm{nd}^{\mathrm{c}}$ \\
\hline 24 & Pinedo 2 & 7.34 & $\mathrm{nd}^{\mathrm{c}}$ & $\mathrm{nd}^{\mathrm{c}}$ & $37.84^{d}$ & $5.22^{\mathrm{d}}$ \\
\hline \multirow[t]{2}{*}{ March 9} & Pinedo 1 & 5.40 & $35.16^{\mathrm{d}}$ & $5.4^{\mathrm{d}}$ & $36.88^{\mathrm{d}}$ & $5.45^{\mathrm{d}}$ \\
\hline & Pinedo 2 & 3.26 & $\begin{array}{l}34.66 \\
35.89\end{array}$ & 5.37 & $35.55^{\mathrm{d}}$ & $5.77^{\mathrm{d}}$ \\
\hline March 11 & $\begin{array}{l}\text { Quart- } \\
\text { Benàger }\end{array}$ & 6.31 & $\begin{array}{l}34.48 \\
34.80\end{array}$ & 5.56 & $\begin{array}{l}36.95 \\
36.95\end{array}$ & 5.43 \\
\hline \multirow[t]{3}{*}{ April 6} & Pinedo 1 & 7.16 & $\begin{array}{l}34.68 \\
34.81\end{array}$ & 5.53 & $\begin{array}{l}34.71 \\
34.69\end{array}$ & 5.98 \\
\hline & Pinedo 2 & 4.51 & $\begin{array}{l}34.81 \\
34.53\end{array}$ & 5.55 & $\begin{array}{l}36.01 \\
36.94\end{array}$ & 5.55 \\
\hline & $\begin{array}{l}\text { Quart- } \\
\text { Benàger }\end{array}$ & 2.60 & $\begin{array}{l}35.19 \\
33.87\end{array}$ & 5.59 & $\begin{array}{l}35.12 \\
34.17\end{array}$ & 5.99 \\
\hline \multirow[t]{2}{*}{ April 9} & Pinedo 1 & 12.07 & $\begin{array}{l}36.02 \\
34.73\end{array}$ & 5.34 & $\begin{array}{l}35.55 \\
36.66\end{array}$ & 5.64 \\
\hline & Pinedo 2 & 18.78 & $\begin{array}{l}34.37 \\
35.48\end{array}$ & 5.47 & $\begin{array}{l}35.91 \\
35.51\end{array}$ & 5.73 \\
\hline April 11 & $\begin{array}{l}\text { Quart- } \\
\text { Benàger }\end{array}$ & 11.17 & $\begin{array}{l}34.58 \\
34.31\end{array}$ & 5.62 & $\begin{array}{l}34.69 \\
35.52\end{array}$ & 5.88 \\
\hline April 13 & $\begin{array}{l}\text { Quart- } \\
\text { Benàger }\end{array}$ & 13.30 & $\begin{array}{l}33.92, \\
34.08\end{array}$ & 5.75 & $\begin{array}{l}35.12, \\
34.66\end{array}$ & 5.93 \\
\hline \multirow[t]{2}{*}{ April 14} & Pinedo 1 & 14.52 & $\begin{array}{l}35.50 \\
34.79\end{array}$ & 5.41 & $35.82^{\mathrm{d}}$ & $5.71^{\mathrm{d}}$ \\
\hline & Pinedo 2 & 10.54 & $\begin{array}{l}35.76, \\
35.2\end{array}$ & 5.31 & $\begin{array}{l}35.12, \\
36.09\end{array}$ & 5.76 \\
\hline
\end{tabular}

${ }^{a}$ PCR region encompassing 2019-nCoV_N1 Combined Primer/Probe Mix.

b PCR region encompassing 2019-nCoV_N2 Combined Primer/Probe Mix.

c Not detected (Ct $>40)$.

d Based on a single technical replicate.

et al., 2020). The recovery efficiency of the virus concentration method was quantitated including a mengovirus internal control and yielded values ranging between 2.56 and $18.78 \%$ in all samples (Table 1). The presence of inhibitors was checked in all the samples. No significant inhibition was detected for any of the samples based on mengovirus $\mathrm{Ct}$ values. This approach was not feasible for SARS-CoV-2 given the high $\mathrm{Ct}$ values for both molecular targets (N1 and N2). Hence, samples from February 24 provide the earliest piece of evidence that the virus was circulating in the community. Interestingly, we consistently detected SARS-CoV-2 RNA in samples collected on March 9 and March 11, when only 50 and 76 cumulative cases were declared in the entire Region of Valencia. This validates wastewater RT-qPCR analysis as a sensitive and reliable technique for early detection of SARS-CoV-2 outbreaks as earlier shown for the Murcia region (Spain) (Randazzo et al., 2020).

For each of the samples collected in April, we also analyzed treated wastewaters, which are routinely discharged to the sea or used for irrigation purposes. We found no evidence of viral RNA in 9/9 samples. These samples provide an additional negative control for our RT-qPCR analysis, reinforcing the conclusion that the signal obtained in untreated waters unlikely corresponds to background signal or non-specific DNA amplification. Importantly, these results confirm that current wastewater treatment procedures efficiently clear the virus.

In conclusion, our results show that the virus was probably undergoing local community transmission by the time the very first cases were declared in the Region of Valencia (Fig. 1). This contrasts with the previously accepted view that, in late February and early March, essentially all COVID-19 cases in Spain were imported or directly traceable through contacts, and that there was no ongoing community transmission at the time. We also find that the RT-qPCR signal in wastewaters increased and reached a plateau faster than declared cases. These results strongly suggest that analysis of wastewaters by RT-qPCR
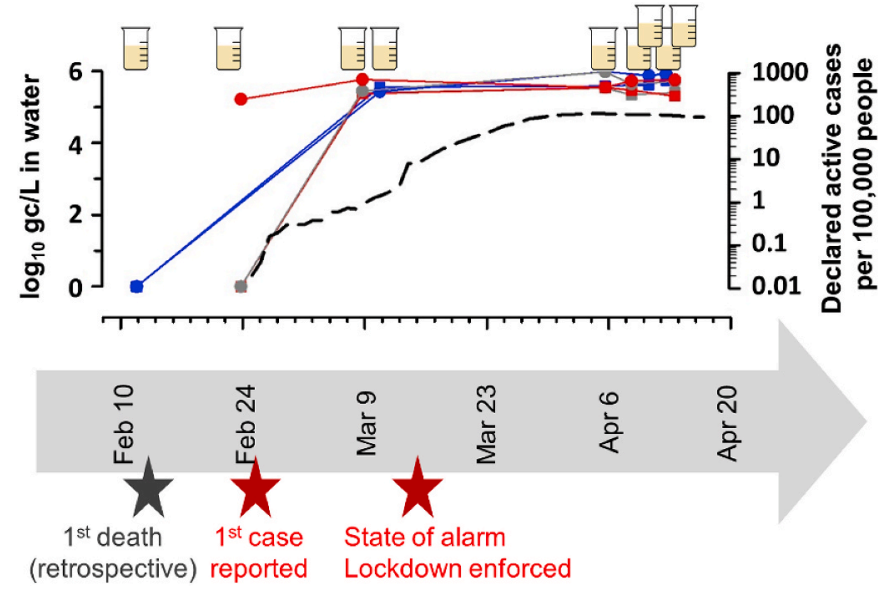

Fig. 1. Series of events and SARS-CoV-2 epidemiological follow-up by wastewater RT-qPCR analysis. Left axis: Mean viral load values as inferred by RTqPCR. For each sampling time point (indicated with beakers), log viral load data shown on Table 1 are plotted. Treatment plants (colors: blue: QuartBenàger, grey: Pinedo 1, red: Pinedo 2) and PCR regions (squares: N1, circles: N2) are indicated. Samples with undetectable RNA levels were arbitrarily assigned a log viral load of zero. Right axis: number of declared active cases in the Region of Valencia per 100,000 people (dashed black line). Bottom: series of events related to the COVID-19 pandemics in the Valencian Region. (For interpretation of the references to color in this figure legend, the reader is referred to the Web version of this article.)

analysis is an efficient strategy for the epidemiological surveillance of COVID-19.

Extreme lockdown measures are currently allowing Spain and other countries to partially mitigate SARS-CoV-2 spread and may help us reduce disease prevalence within the next weeks or months. However, inevitable relaxation of current containment measures may lead to recurring local outbreaks or case imports from other regions. As such, it is of extreme importance to set up feasible and reliable epidemiological surveillance strategies that will improve our preparedness in the event of future viral re-emergencies.

\section{Role of the funding source}

The funding sources had no rule in the study design, data collection, analysis of data, writing, or in the decision to publish.

\section{Author contributions}

W.R. performed the experiments and analyzed data; E.C-F. performed the experiments; R.S. analyzed data and co-wrote manuscript; P. D-C. conceived study, obtained the samples, analyzed data, and cowrote manuscript; G.S. conceived study and supervised work. All authors have read and agreed to the published version of the manuscript.

\section{Declaration of interests}

The authors declare that they have no known competing financial interests or personal relationships that could have appeared to influence the work reported in this paper.

\section{Acknowledgments}

We thank the Generalitat Valenciana and the Empresa Pública de Saneamiento de Aguas Residuales (EPSAR) for providing access to wastewater. This research was funded by CSIC 202070E101 grant, 210152 project of Valencian Innovation Agency/GV, and AGL201782909 (AEI/FEDER, UE) funded by Spanish Ministry of Science, 
Innovation and Universities to G.S., ERC Consolidator Grant 724519Vis-à-Vis to R.S. and FONDO-COVID19 COV20/00210 funded by Instituto de Salud Carlos III to P.D-C. W.R. was supported by APOSTD/2018/ 150 postdoctoral fellowship, and E.C-F. was supported by a predoctoral contract from the MICINN, Call 2018.

\section{References}

[ERROR!: PLEASE CHECK REFERENCE STYLE] 9510 detection of enteric viruses (2017), 2018. Standard methods for the examination of water and wastewater. Am J Public Health. https://doi.org/10.2105/SMWW.2882.202.

Ahmed, W., Angel, N., Edson, J., Bibby, K., Bivins, A., O’Brien, J.W., Choi, P.M., Kitajima, M., Simpson, S.L., Li, J., Tscharke, B., Verhagen, R., Smith, W.J.M., Zaugg, J., Dierens, L., Hugenholtz, P., Thomas, K.V., Mueller, J.F., 2020. First confirmed detection of SARS-CoV-2 in untreated wastewater in Australia: a proof of concept for the wastewater surveillance of COVID-19 in the community. Sci. Total Environ. 728, 138764. https://doi.org/10.1016/j.scitotenv.2020.138764.

Bivins, A., North, D., Ahmad, A., Ahmed, W., Alm, E., Been, F., Bhattacharya, P., Bijlsma, L., Boehm, A.B., Brown, J., Buttiglieri, G., Calabro, V., Carducci, A., Castiglioni, S., Cetecioglu Gurol, Z., Chakraborty, S., Costa, F., Curcio, S., de los Reyes, F.L., Delgado Vela, J., Farkas, K., Fernandez-Casi, X., Gerba, C., Gerrity, D., Girones, R., Gonzalez, R., Haramoto, E., Harris, A., Holden, P.A., Islam, MdT., Jones, D.L., Kasprzyk-Hordern, B., Kitajima, M., Kotlarz, N., Kumar, M., Kuroda, K., La Rosa, G., Malpei, F., Mautus, M., McLellan, S.L., Medema, G., Meschke, J.S., Mueller, J., Newton, R.J., Nilsson, D., Noble, R.T., van Nuijs, A., Peccia, J., Perkins, T.A., Pickering, A.J., Rose, J., Sanchez, G., Smith, A., Stadler, L., Stauber, C., Thomas, K., van der Voorn, T., Wigginton, K., Zhu, K., Bibby, K., 2020. Wastewaterbased epidemiology: global collaborative to maximize contributions in the fight against COVID-19. Environ. Sci. Technol. 54, 7754-7757. https://doi.org/10.1021/ acs.est.0c02388.

Chen, Y., Chen, L., Deng, Q., Zhang, G., Wu, K., Ni, L., Yang, Y., Liu, B., Wang, W., Wei, C., Yang, J., Ye, G., Cheng, Z., 2020. The presence of SARS-CoV-2 RNA in feces of COVID-19 patients. J. Med. Virol. 92, 7. https://doi.org/10.1002/jmv.25825.

Cheung, K.S., Hung, I.F.N., Chan, P.P.Y., Lung, K.C., Tso, E., Liu, R., Ng, Y.Y., Chu, M.Y., Chung, T.W.H., Tam, A.R., Yip, C.C.Y., Leung, K.-H., Yim-Fong Fung, A., Zhang, R.R., Lin, Y., Cheng, H.M., Zhang, A.J.X., To, K.K.W., Chan, K.-H., Yuen, K.-Y., Leung, W. K., 2020. Gastrointestinal manifestations of SARS-CoV-2 infection and virus load in fecal samples from the Hong Kong cohort and systematic review and meta-analysis. Gastroenterology. https://doi.org/10.1053/j.gastro.2020.03.065.

Chin, A.W.H., Chu, J.T.S., Perera, M.R.A., Hui, K.P.Y., Yen, H.-L., Chan, M.C.W., Peiris, M., Poon, L.L.M., 2020. Stability of SARS-CoV-2 in different environmental conditions. The Lancet Microbe 1, e10. https://doi.org/10.1016/S2666-5247(20) 30003-3.

Corman, V.M., Landt, O., Kaiser, M., Molenkamp, R., Meijer, A., Chu, D.K., Bleicker, T., Brünink, S., Schneider, J., Schmidt, M.L., Mulders, D.G., Haagmans, B.L., Van der Veer, B., Van den Brink, S., Wijsman, L., Goderski, G., Romette, J.-L., Ellis, J., Zambon, M., Peiris, M., Goossens, H., Reusken, C., Koopmans, M.P., Drosten, C., 2020. Detection of 2019 novel coronavirus (2019-nCoV) by real-time RT-PCR. Euro Surveill. 25, 2000045. https://doi.org/10.2807/1560-7917.ES.2020.25.3.2000045.

Cuevas-Ferrando, E., Randazzo, W., Pérez-Cataluña, A., Sánchez, G., 2020. HEV occurrence in waste and drinking water treatment plants. Front. Microbiol. 10 https://doi.org/10.3389/fmicb.2019.02937.

Duan, S.-M., Zhao, X., Wen, R.-F., Huang, J.-J., Pi, G.-H., Zhang, S.-X., Han, J., Bi, S.-L., Ruan, L., Dong, X.-P., Team, S.R., 2003. Stability of SARS coronavirus in human specimens and environment and its sensitivity to heating and UV irradiation. BES (Biomed. Environ. Sci.) 16, 246-255.

Haramoto, E., Kitajima, M., Hata, A., Torrey, J.R., Masago, Y., Sano, D., Katayama, H., 2018. A review on recent progress in the detection methods and prevalence of human enteric viruses in water. Water Res. 135, 168-186. https://doi.org/10.1016/ j.watres.2018.02.004.

Haramoto, E., Malla, B., Thakali, O., Kitajima, M., 2020. First environmental surveillance for the presence of SARS-CoV-2 RNA in wastewater and river water in Japan. Sci. Total Environ. 737, 140405. https://doi.org/10.1016/j.scitotenv.2020.140405.

Heijnen, L., Medema, G., 2011. Surveillance of influenza A and the pandemic influenza A (H1N1) 2009 in sewage and surface water in The Netherlands. J. Water Health 9, 434-442. https://doi.org/10.2166/wh.2011.019.

Hellmér, M., Paxéus, N., Magnius, L., Enache, L., Arnholm, B., Johansson, A., Bergström, T., Norder, H., 2014. Detection of pathogenic viruses in sewage provided early warnings of hepatitis A virus and norovirus outbreaks. Appl. Environ. Microbiol. 80, 6771-6781. https://doi.org/10.1128/AEM.01981-14.
Hovi, T., Shulman, L.M., van der Avoort, H., Deshpande, J., Roivainen, M., DE Gourville, E.M., 2012. Role of environmental poliovirus surveillance in global polio eradication and beyond. Epidemiol. Infect. 140, 1-13. https://doi.org/10.1017/ S095026881000316X.

La Rosa, G., Iaconelli, M., Mancini, P., Bonanno Ferraro, G., Veneri, C., Bonadonna, L., Lucentini, L., Suffredini, E., 2020. First detection of SARS-CoV-2 in untreated wastewaters in Italy. Sci. Total Environ. 736, 139652. https://doi.org/10.1016/j. scitotenv.2020.139652.

Lescure, F.-X., Bouadma, L., Nguyen, D., Parisey, M., Wicky, P.-H., Behillil, S., Gaymard, A., Bouscambert-Duchamp, M., Donati, F., Hingrat, Q.L., Enouf, V., Houhou-Fidouh, N., Valette, M., Mailles, A., Lucet, J.-C., Mentre, F., Duval, X., Descamps, D., Malvy, D., Timsit, J.-F., Lina, B., van-der-Werf, S., Yazdanpanah, Y., 2020. Clinical and virological data of the first cases of COVID-19 in Europe: a case series. Lancet Infect. Dis. 20, 697-706. https://doi.org/10.1016/S1473-3099(20) 30200-0.

Li, H., Liu, L., Zhang, D., Xu, J., Dai, H., Tang, N., Su, X., Cao, B., 2020. SARS-CoV-2 and viral sepsis: observations and hypotheses. Lancet 395. https://doi.org/10.1016/ S0140-6736(20)30920-X, 14717-1520.

Lo, I.L., Lio, C.F., Cheong, H.H., Lei, C.I., Cheong, T.H., Zhong, X., Tian, Y., Sin, N.N., 2020. Evaluation of SARS-CoV-2 RNA shedding in clinical specimens and clinical characteristics of 10 patients with COVID-19 in Macau. Int. J. Biol. Sci. 16, 1698-1707. https://doi.org/10.7150/ijbs.45357.

Lodder, W., de Roda Husman, A.M., 2020. SARS-CoV-2 in wastewater: potential health risk, but also data source. Lancet Gastroenterol. Hepatol. 5, 533-534. https://doi. org/10.1016/S2468-1253(20)30087-X.

Medema, G., Heijnen, L., Elsinga, G., Italiaander, R., Brouwer, A., 2020. Presence of SARS-coronavirus-2 RNA in sewage and correlation with reported COVID-19 prevalence in the early stage of the epidemic in The Netherlands. Environ. Sci. Technol. Lett. https://doi.org/10.1021/acs.estlett.0c00357.

Ministerio de Sanidad. Consumo y Bienestar Social - Professionals - Enfermedad por nuevo coronavirus, COVID-19 [WWW Document]. accessed 4.22.2020. https:// www.mscbs.gob.es/en/profesionales/saludPublica/ccayes/alertasActual/nCov-Ch ina/home.htm.

Nalla, A.K., Casto, A.M., Huang, M.-L.W., Perchetti, G.A., Sampoleo, R., Shrestha, L., Wei, Y., Zhu, H., Jerome, K.R., Greninger, A.L., 2020. Comparative performance of SARS-CoV-2 detection assays using seven different primer-probe sets and one assay Kit. J. Clin. Microbiol. 58 https://doi.org/10.1128/JCM.00557-20 e00557-20.

Randazzo, W., Piqueras, J., Evtoski, Z., Sastre, G., Sancho, R., González, C., Sánchez, G., 2019. Interlaboratory comparative study to detect potentially infectious human enteric viruses in influent and effluent waters. Food Environ. Virol. 11, 350-363. https://doi.org/10.1007/s12560-019-09392-2.

Randazzo, W., Truchado, P., Cuevas-Ferrando, E., Simón, P., Allende, A., Sánchez, G., 2020. SARS-CoV-2 RNA in wastewater anticipated COVID-19 occurrence in a low prevalence area. Water Res. 181, 115942. https://doi.org/10.1016/j. watres.2020.115942.

Santiso-Bellón, C., Randazzo, W., Pérez-Cataluña, A., Vila-Vicent, S., Gozalbo-Rovira, R., Muñoz, C., Buesa, J., Sanchez, G., Rodríguez Díaz, J., 2020. Epidemiological surveillance of norovirus and rotavirus in sewage (2016-2017) in Valencia (Spain). Microorganisms 8, 458. https://doi.org/10.3390/microorganisms8030458.

Sun, J., Zhu, A., Li, H., Zheng, K., Zhuang, Z., Chen, Z., Shi, Y., Zhang, Z., Chen, S., Liu, X., Dai, J., Li, X., Huang, S., Huang, X., Luo, L., Wen, L., Zhuo, J., Li, Yuming, Wang, Y., Zhang, L., Zhang, Y., Li, F., Feng, L., Chen, X., Zhong, N., Yang, Z., Huang, J., Zhao, J., Li, Yi-min, 2020. Isolation of infectious SARS-CoV-2 from urine of a COVID-19 patient. Emerg. Microb. Infect. 9, 991-993. https://doi.org/10.1080/ 22221751.2020.1760144.

Wang, W., Xu, Y., Gao, R., Lu, R., Han, K., Wu, G., Tan, W., 2020. Detection of SARS-CoV2 in different types of clinical specimens. J. Am. Med. Assoc. 323, 1843-1844. https://doi.org/10.1001/jama.2020.3786.

Wu, Y., Guo, C., Tang, L., Hong, Z., Zhou, J., Dong, X., Yin, H., Xiao, Q., Tang, Y., Qu, X., Kuang, L., Fang, X., Mishra, N., Lu, J., Shan, H., Jiang, G., Huang, X., 2020. Prolonged presence of SARS-CoV-2 viral RNA in faecal samples. Lancet Gastroenterol. Hepatol. 5, 434-435. https://doi.org/10.1016/S2468-1253(20) 30083-2.

Xing, Y.-H., Ni, W., Wu, Q., Li, W.-J., Li, G.-J., Wang, W.-D., Tong, J.-N., Song, X.-F., Wing-Kin Wong, G., Xing, Q.-S., 2020. Prolonged viral shedding in feces of pediatric patients with coronavirus disease 2019. J. Microbiol. Immunol. Infect. 53, 473-480. https://doi.org/10.1016/j.jmii.2020.03.021.

Zhang, T., Cui, X., Zhao, X., Wang, J., Zheng, J., Zheng, G., Guo, W., Cai, C., He, S., $\mathrm{Xu}, \mathrm{Y} ., 2020$. Detectable SARS-CoV-2 viral RNA in feces of three children during recovery period of COVID-19 pneumonia. J. Med. Virol. 92, 7. https://doi.org/ 10.1002/jmv.25795. 